\title{
Degludek: napjaink ideális bázisinzulinja?
}

\author{
Gerő László dr.
}

\begin{abstract}
Összefoglalás
A degludek egy ultrahosszú hatású bázis-inzulinanalóg, amelyböl a B30-as pozíciójú treonint eltávolitották és a B29-es lizinhez egy 16 szénatomos zsirsavat kapcsoltak. Az injekció beadása után a degludek a subcutan térben oldékony multihexamereket képez. A cinkionok fokozatos kiválását követöen a multihexamer láncok mindkét végéröl monomer inzulinok válnak le, amelyek lassan abszorbeálódva jutnak át a keringésbe. A degludek inzulint az elnyújtott, 42 órás hatástartam és a rendkivül egyenletes hatásprofil jellemzi, ami állandó és stabil glukózcsökkentö hatást biztosit alacsony glukózvariabilitással. Randomizált, prospektiv, keresztezett elrendezésü, kettös vak tanulmányokban a degludekkezelés szignifikánsan kevesebb hypoglykaemiát okozott, mint a glargin-100 inzulin kezelés. Egy kardiovaszkuláris biztonságossági tanulmányban a degludek inzulin non-inferiornak bizonyult a glargin-100 inzulinhoz képest. Egy retrospektív obszervációs vizsgálatban a degludekkezelés szignifikánsan nagyobb $\mathrm{HbA}_{1 c}$-szint-csökkenést és kevesebb hypoglykaemiát okozott, mint a glargin-300 inzulin, s a terápiahüség is nagyobb volt a degludekkezelés mellett. A kisebb hypoglykaemia-kockázat lehetövé teszi a napi inzulinadag erélyesebb titrálását és a beteg számára stabil, alacsonyabb glykaemiás tartomány biztonságos elérését - ami az évek során csökkentheti a diabetes késöi vascularis szövődményeinek kialakulását, illetve lassithatja azok progresszióját. A leirrtak alapján a degludek inzulin napjaink ideális bázisanalóg-készitményének tekinthetö.

Kulcsszavak: degludek inzulin, glargin inzulin, glukózvariabilitás, hypoglykaemia
\end{abstract}

\section{Degludec: the ideal basal insulin of today}

Summary: Insulin degludec is an ultra-long-acting basal insulin from which threonin B30 has been removed and lysin B29 is acylated with a 16-carbonic fatty acid. Degludec forms soluble multihexamers after subcutaneous injection. Following the decrease of zinc ion content, monomer insulins will dissociate from both ends of the multihexamer chain and these monomers will be slowly absorbed and get into the circulation. Degludec is characterized by a protracted action time of 42 hours and an extremely smooth action profile providing a flat and stable glucose-lowering effect with minimal variability. In prospecive, randomized, double-blind crossing-over clinical studies the use of degludec insulin was associated with significantly less hypoglycaemia than insulin glargine-100. Furthermore, degludec proved to be non-inferior to insulin glargin-100 in a cardiovascular safety trial. In a retrospective, observational study the degludec treatment resulted in significantly lower $\mathrm{HbA}_{1 \mathrm{c}}$ level and less hypoglycaemia and longer therapeutical adherence than glargin-300 insulin. The lower rate of hypoglycaemia allows more aggressive titration of insulin and the achievement of a stable lower glycaemia for the patient - with the hope of avoiding the late vascular complications in the future. Taking all together, degludec seems to be the ideal basal analog insulin of today.

Keywords: insulin degludec, insulin glargine, glucose variability, hypoglycaemia

Rövidítések

ERR: estimated rate ratio (becsült rátaarány); GIR: glukózinfúziós ráta; NPH: Neutral Protamin Hagedorn; OAD: orális antidiabetikum; sc: subcutan 


\section{Az inzulin hatásának elnyújtására szolgáló kémiai módszerek}

Az első beteg, akinek életét az inzulin megmentette, a 14 éves Leonard Thompson, még „kvadlikban”, 4-6 óránként kapta az inzulint. A gyógyszer felfedezése és első klinikai alkalmazása után még közel másfél évtizeden át csak rövid hatású készítmények álltak rendelkezésünkre. Az elhúzódó hatású készítmények az 1930-as években jelentek meg, elsősorban Hagedorn úttörő munkásságának köszönhetően, akinek nevéhez a Zn-protamin inzulin kifejlesztése (más néven: neutral protamin Hagedorn, NPH inzulin) füződik. A Zn-protamin inzulint általában naponta egyszer vagy kétszer adták, hatása bő félnapig tartott.

A cink és a protamin az inzulinnal precipitátumot képez, amelyben az inzulin:protamin arány átlagosan 5:1. Mivel a subcutan térbe kerülő precipitátumok nagysága injekcióról injekcióra változik, és ezzel együtt módosulhat a fenti arány is, a Zn-protamin inzulin felszívódásának sebessége, vérszintje és így hatásának variabilitása is injekcióról injekcióra változik. Ennek ellenére, a humán inzulinok hatásának meghosszabbításához jelenleg is ezt a módszert használjuk.

A bázisanalóg inzulinok hatásának elnyújtására azonban már újabb módszereket dolgoztak ki. Az első bázisanalóg, a glargin inzulin szerkezetét úgy alakították ki, hogy az A21-es pozíciójú aszparagint glicinre cserélték (a molekula nagyobb stabilitása érdekében), a B-láncot pedig meghosszabbították két bázikus argininnal (B31-B32 di-arginin). Ezzel a módosítással a molekula izoelektromos pontja megváltozott, oldékonysága savi pH mellett (pH: 4,00) optimális. Amikor az inzulint a subcutan térbe juttatjuk, az enyhén bázikus pH-jú (pH: 7,40) környezetben mikroprecipitátumokat képez, amelyekből lassan, fokozatosan válnak le az inzulin-monomerek és jutnak át a keringésbe. A kialakuló precipitátumok nagysága viszont különbözik és a disszociációs felület is változik az adagolási intervallum során, így a precipitátum-kristályról leváló és a keringésbe jutó inzulin mennyisége is időről időre változik. Mindennek ellenére a glargin inzulin kezelés mellett a szérum inzulinszintje lényegesen egyenletesebb, mint az NPH inzulin kezelés mellett.

Mivel a precipitátumok teljes felületéről történik a monomer inzulin leválása, ahogy kisebbedik egy adott precipitátum, úgy lesz egyre kisebb a monomert „kibocsájtó” felület. Emiatt az injekciózást követő nap második felében a subcutan térből a véráramba átjutó inzulin mennyisége fokozatosan csökken. A glargin hatástartama mintegy 20-22 óra, de az utolsó órákban a hatás a leírtaknak megfelelően már lényegesen gyengül.

A glargint az esetek többségében naponta egyszer adjuk, de vannak labilis anyagcseréjü, 1-es típusú diabeteses betegek, akik napi kétszeri injekciót igényelnek. . $^{1,23}$

A következő piacra kerülő bázisinzulin, a detemir kémiai szerkezetének kialakításánál alkalmazták először a zsírsavas acilálást: az inzulin B-láncának utolsó, 30-as pozíciójú aminosavát, a treonint elhagyták, és a B29-es pozíciójú lizinhez egy 14 szénatomszámú zsírsavat, a mirisztinsavat kötötték. A zsírsavlánc elősegíti az inzulinmolekula albuminhoz való kötődését. A subcutan térben a detemir di-hexamereket képez, amelyekből lassan, egyenletesen válnak ki az inzulin-monomerek. Az albumin-kötődés már a subcutan térben is létrejön. Ha tehát a felszívódás valamiért ingadozna (pl. a keringés, illetve a perfúzió átmeneti zavara miatt), akkor azt az albuminhoz kötött detemir „pufferolni” képes. Ezután a lassan, fokozatosan felszívódó inzulin a keringésben először szintén albuminhoz kötődik, majd az inzulinreceptorok szabaddá válásával átkerül az albuminról a receptorra. Mindez - az albumin pufferoló hatása miatt - rendkívül egyenletes, jól kiszámítható és reprodukálható inzulinhatást biztosít.

A detemir hatástartama 16-20 óra, így 2-es típusú diabetesben (T2DM-ben) naponta egyszer, 1-es típusban (T1DM-ben) egyszer vagy kétszer kell adagolni. Több vizsgálatban a detemir inzulin adása mellett kisebb volt a súlynövekedés, mint más bázisinzulinok alkalmazása mellett, sőt enyhe, de statisztikailag szignifikáns súlycsökkenést is megfigyeltek. ${ }^{4,5}$

A detemir után jelent meg a piacon a degludek inzulin. Kémiai szerkezetét a detemirhez hasonlóan alakították ki: a B30-as pozíciójú aminosavat itt is elhagyták, és egy glutamin „spacer”-en át a B29-es aminosavhoz egy 16-szénatomos diacil-zsírsavláncot (palmitin-diacil) kötöttek. Ez az inzulin - fenol és cink jelenlétében - di-hexamerekké áll össze a beadóeszközben. Beadást követően a fenol kiválásával a di-hexamerek két oldala „kinyílik”, és 
a di-hexamerekből a subcutan térben 1000-1500 tagú multihexamerek képződnek.

A cinkionok fokozatos kidiffundálásával elindul a multihexamerek lebomlása: a hosszú hexamer lánc mindkét oldaláról fokozatosan és egyenletes sebességgel válnak le a monomer inzulinok, és jutnak át a keringésbe (1. ábra). Hangsúlyozni kell, hogy a multihexamer lánc rövidülésével a monomerek leválásának sebessége nem változik, mivel a lánc mindkét végéről továbbra is egyenletes sebességgel válnak le a hexamerek, hiszen a disszociációs felület állandó. A keringésben a degludek-monomerek először albuminhoz kötődnek, majd a detemirnél leírt mechanizmussal kerülnek át a szabaddá váló inzulinreceptorokra. A leírt folyamat kivételesen egyenletes felszivódást és hatásprofilt tesz lehetővé - amint azt a klinikai vizsgálatok is megerősítették. A degludek hatástartama 42 óra, ami a leghosszabb a ma elérhető bázisanalógok között. ${ }^{6,7}$

A degludek inzulin után jelent meg a piacon a $300 \mathrm{NE} / \mathrm{ml}$ töménységű glargin (glargin-300) inzulin. Kémiailag azonos szerkezetű a $100 \mathrm{NE} / \mathrm{ml}$ töménységű glarginnal (glargin-100), de a készítményben az inzulin koncentrációját háromszorosra növelték. Emiatt az egységnyi inzulin kiáramlására kisebb felület áll rendelkezésre, és így a glargin-300 a subcutan térből lassabban jut át a keringésbe. A hatástartam viszont így hosszabb: 26-28 óra. Mind a degludek-, mind a glargin-300 kezelés mellett szignifikánsan kisebb a vércukorszint variabilitása és kevesebb a hypoglykaemia, mint a glargin-100 inzulin kezelés mellett.

\section{Miért fontos az egyenletes inzulinfelszívódás?}

Ma már számos követéses klinikai vizsgálat eredménye szól amellett, hogy mind a beteg életminőségének javítása, mind a késői szövődmények kivédése szempontjából alapvető fontosságú a glukózvariabilitás - lehetőség szerinti - minimumra csökkentése. ${ }^{8}$ A kisebb variabilitás mellett ugyanis egyrészt alacsonyabbak lesznek a postprandialis vércukorszintek - és ez a vascularis szövődmények kivédésének vagy progressziójuk leállításának alapvető feltétele. Másrészt a kisebb variabilitás mellett kevesebb lesz a hypoglykaemia. A hypoglykaemia az erélyes és hatékony inzulinkezelés egyik legfontosabb gátja, gyakorlatilag lehetetlenné teszi

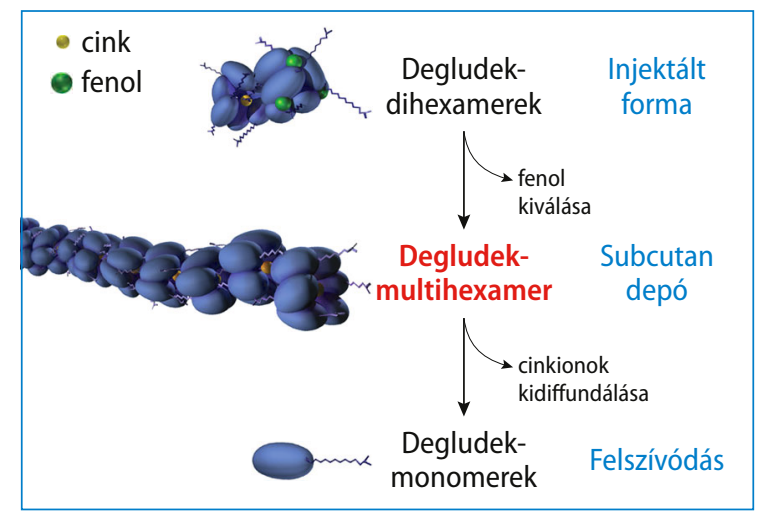

1. ábra. A degludek inzulin a subcutan zsírszövetben oldható multihexamer láncokat képez, majd a cinkionok kidiffundálása után a lánc minkét oldaláról folyamatosan válnak le a monomer inzulinok és egyenletes sebességgel jutnak a keringésbe

inzulinnal kezelt betegeinkben a normoglykaemia elérését. Szövődményei kissé különböznek az idős és a fiatalabb betegekben.

Idős, koszorúérszükületben szenvedő betegekben a hypoglykaemia egyrészt angina pectorist (esetleg szívinfarktust) válthat ki, másrészt növelheti a veszélyes kamrai tachycardia (torsades de pointes) és ventrikuláris aritmiák kialakulását, ami akár kamrafibrillációba is átmehet, és fatális kimenetelü lehet. Idős betegekben tehát a hypoglykaemia növelheti a szívhalál kockázatát. ${ }^{9} 10$

A hypoglykaemia a fiatalabb korosztályban is számos kellemetlen késői tünettel járhat. Az éjszakai hypoglykaemia másnapra, a Somogyi-effektus révén akár 6-72 órán át is elhúzódó reaktív hyperglykaemiát okozhat. Még az ennél enyhébb reakciók is a következő napokban levertséget, fejfájást, a munkaképesség csökkenését válthatják ki. Egy felmérésben a hypoglykaemiát követő munkanapon a betegek $60 \%$-a számolt be nyomott közérzetről, gyengeségről, fejfájásról és 40,2\%-uk korábban ment másnap haza a munkahelyéről, és korábban ment lefeküdni is. ${ }^{11}$

A fent leírt tünetek lényegesen ritkábban fordulnak elő, ha az adott inzulinkezelés mellett kisebb a glukózvariabilitás.

A továbbiakban a degludek inzulin kezelés mellett talált glukózvariabilitást és hypoglykaemia-gyakoriságot tekintjük át. Az adatok 3-as 
fázisú, randomizált, kontrollos tanulmányok, valamint metaanalízisek és obszervációs vizsgálatok eredményein alapulnak. A vizsgálatokban kontrollkészítményként általában glargin-100 inzulin szerepelt, de néhány újabb tanulmányban a degludek inzulin és a glargin-300 inzulin melletti glukózvariabiltást és hypoglykaemia-gyakoriságot is összehasonlították. Végezetül összefoglaljuk a degludek-tanulmányok eredményeiből levonható terápiás következtetéseket.

\section{Az inzulinhatás variabilitása: a degludek és a glargin-100 inzulinok összehasonlítása}

A degludek és a glargin-100 inzulinok hatásprofilját Heise és mtsai hasonlították össze egy randomizált, kettős vak tanulmányban. ${ }^{12} \mathrm{~A}$ vizsgálatba összesen 54, 1-es típusú (T1DM) beteget vontak be, a betegek életkora $18-65$ év, átlagos $\mathrm{HbA}_{1 c}$-értékük $8,3 \%$ volt, $\mathrm{s}$ a cukorbetegség már több mint 1 éve fennállt. A bevonás feltétele volt még, hogy a C-peptid-szint a kimutathatósági határ alatt, a napi inzulinigény 1,2 NE/tskg alatt legyen.

A betegek naponta 3-szor aszpart inzulint és lefekvéskor bázisanalóg-készítményt kaptak, utóbbit a vizsgálat előtt randomizált besorolás szerint $0,4 \mathrm{NE} / \mathrm{tskg}$ degludek vagy glargin-100 inzulinra váltották. A terápia 6., 9., 12. napján euglykaemiás clamp vizsgálat történt: ezen a napon a betegek gyors hatású inzulint már nem kaptak, csak a bázisinzulint adták be, s a beadása után annak vércukorcsökkentő hatását glukózinfúzióval ellensúlyozták úgy, hogy a nap folyamán a vércukorszint 5,0 mmol/l szinten állandósuljon. A két bázisinzulin hatékonyságát, annak változását az óránként bejuttatott glukóz mennyiségével jellemezték (glukózinfúziós ráta: GIR).

A teszt eredménye szerint az inzulinok vércukorcsökkenő hatásának napok közötti variabilitása négyszer volt kisebb a degludek, mint a glargin-100 inzulin kezelés mellett - variabilitás: $20 \%$ vs. $82 \%$ $(\mathrm{p}<0,0001)$. Egy érdekes „mellékeredménye” volt a vizsgálatnak, hogy a glargin-100 inzulin glykaemiás hatása beadást követően 6 órával kifejezetten variabilissá vált, és ez a fokozott változékonyság kb. a beadást követő 16 . óráig tartott, majd ezt követően csökkent. A degludek variabilitása viszont állandó maradt a teljes 24 órán át.
Egy további hasonló, de keresztezett elrendezésủ clamp vizsgálatban összesen 66 T1DM-es betegen hasonlították össze a degludek és a glargin-100 hatásának variabilitását. A betegek randomizált besorolás szerint vagy degludek, vagy glargin-100 kezdő kezelést kaptak. Ezen belül a betegeket három kezelési csoportra osztották, az első csoport 0,4 NE/tskg, a második 0,6 NE/tskg, a harmadik csoport 0,8 NE/tskg dózisban kapta a bázisinzulint 6-6 napon át. A két kezelési periódus végén 42 órás clamp vizsgálatot végeztek, majd a keresztezett elrendezésnek megfelelően megtörtént az inzulinváltás, és a betegek az ellenkező inzulint kapták, majd 6 napos kezelést követően ismét 42 órás clamp vizsgálatra került sor. (A módszer alapvetően hasonló volt az előzőkben leírtakhoz. A kétféle kezelési periódust 7-21 napos kimosási periódus választotta el).

A clamp vizsgálat alapján az inzulinok féléletideje a degludek esetén 25,4 órának, a glargin-100 esetén 12,1 órának adódott. A degludek hatása egyenletesnek bizonyult az egész vizsgálat folyamán. A hatáserősség arányosan nőtt az alkalmazott dózis nagyságával. A glargin-100 inzulin hatása nem csak rövidebb, hanem a nap folyamán egyenetlenebb is volt, elsősorban a vizsgálat 12-18. órája között. Ezenkívül a hatás variabilitása meredekebben nőtt a nagyobb inzulindózisok alkalmazása mellett. Ezt jól érzékeltetik a bevitt glukózmennyiségek változásai is: $0,25-0,37-0,38$ $\mathrm{mg}$ glukóz $/ \mathrm{kg} \times$ min a degludek inzulin $0,4-0,6-0,8$ $\mathrm{NE} / \mathrm{tskg}$ adagjai mellett és $0,39-0,54-0,73 \mathrm{mg}$ glukóz/kg $\times$ min a glargin-100 inzulin hasonló dózisokkal végzett clamp vizsgálata mellett. ${ }^{13}$

\section{Az inzulinhatás variabilitása: degludek inzulin összehasonlítása glargin-300 inzulinnal}

A degludek és a glargin-300 inzulinok hatásának variabilitására vonatkozóan két összehasonlító clamp tanulmány eredménye is rendelkezésünkre áll.

Az egyiket Heise és mtsai végezték: a kettős vak, keresztezett elrendezésű vizsgálatban összesen 57 T1DM-es betegen hasonlították össze a két inzulin hatásának napon belüli (24 órás) és napok közötti variabilitását. ${ }^{14} \mathrm{~A}$ bevonási feltételek közé tartozott a legalább egyéves diabetestartam, a 
18,5-29,0 kg/m² közötti testtömegindex, a 9,0\%-ot meg nem haladó $\mathrm{HbA}_{1 \mathrm{c}}$-szint, a kimutathatósági határérték alatti C-peptid-szint és az 1,2 NE/tskg alatti napi inzulinigény.

A betegeket randomszerūen sorolták 12 napos, 0,4 NE/tskg dózisú degludek vagy glargin-300 kezelésre, majd kimosást követően a keresztezett elrendezésnek megfelelően a betegek áttértek a másik bázisinzulinnal végzett 12 napos kezelésre. A főétkezések előtt ezt a kezelést szükség szerint bólusokban adott aszpart inzulinnal egészítették ki. A két bázisinzulint egy erre alkalmazott (a vizsgálatban egyébként részt nem vevő) független személy adta be sc, a fecskendőn nem volt semmilyen jelzés, ami az inzulin típusára vonatkozott volna, így biztosították a vizsgálat „kettős vak” jellegét. $\mathrm{Az}$ injekció beadása este 8.00-kor történt, és gondosan ügyeltek arra, hogy az egyes injekciózások között pontosan 24 óra teljen el.

$\mathrm{Az}$ első és második 12 napos kezelési periódus 6., 9., 12. napján clamp vizsgálatot végeztek. A betegek a vizsgálat reggelén szükség szerint intravénás infúzióban gyors hatású humán inzulint vagy glukózt kaptak, hogy beállítsák a cél-vércukorszintet $(5,5 \mathrm{mmol} / \mathrm{l})$. A clamp napján az aszpart inzulin adását már felfüggesztették, és a $0,4 \mathrm{NE} /$ tskg bázisinzulin hatását infúzióban bevitt glukóz adásával ellensúlyozták, hogy a cél-vércukorszint fenntartását folyamatosan biztosítsák. A betegek egyébként éhgyomorra maradtak a clamp teljes időtartama alatt. A glukózinfúziós ráta (GIR) görbéinek alakulásából kalkulálható volt az inzulinkészítmények vércukorcsökkentő hatásának variabilitása, valamint vércukorcsökkentő potenciálja.

A GIR görbe alatti területek $\left(\mathrm{AUC}_{\mathrm{GIR}}\right)$, azaz a 24 óra alatt infundált glukózmennyiségek összevetése révén megadható a két bázisinzulin egymáshoz viszonyított vércukorcsökkentő potenciálja. Ez alapján a glargin-300 inzulin vércukorcsökkentő potenciálja 30\%-kal kisebbnek bizonyult a degludek inzulinéhoz képest (becsült arány: 0,70, 95\%os CI: $0,61-0,80 ; \mathrm{p}<0,0001)$.

A két inzulin melletti variabilitást összehasonlítva, a degludekkezelés mellett a relatív napon belüli variabilitás $37 \%$-kal volt kisebb, mint a glargin-300 mellett - degludek:glargin-300 variabilitási arány: 0,63 (95\%-os CI: 0,54-0,73, p<0,0001). A napon belüli variabilitást azért volt indokolt relatív értékben megadni, mert jelentős az eltérés a két inzulinkészítmény vércukorcsökkentő potenciáljában (bővebb magyarázatot lásd később).

A vércukorcsökkentő hatás napon belüli változékonyságát úgy is jellemezhetjük, hogy 6 órás intervallumokra bontva kiszámítjuk az infundált glukóz mennyiségének, azaz az $\mathrm{AUC}_{\mathrm{GIR}}$ értéknek a napon belüli százalékos megoszlását. A degludek clamp során a 6 órás $\mathrm{AUC}_{\mathrm{GIR}}$ értékek a napi összes beadott glukóz százalékában kifejezve $24 \%$ és $26 \%$ között mozogtak, ami kifejezetten egyenletes hatást jelez (ideális esetben 25-25\% az egyes időintervallumokra nézve). A glargin-300 clamp során - szintén $4 \times 6$ órás intervallumokra osztva a 24 órás clamp tanulmányt - a bevitt glukóz mennyiségének százalékos eloszlása $35,2 \%-20,2 \%$ - 16,6\% és $28,0 \%$ volt.

A glukózcsökkentő hatás napok közötti variabilitása csaknem 4-szer volt kisebb a degludek, mint a glargin-300 mellett, a varianciaarány glargin-300: degludek $=3,70 ; 95 \%$-os CI: 2,42-5,67, p<0,0001. A napok közötti varianciát 2 óránkénti intervallumokra bontva a variancia különbsége (a degludek javára) minden időpontban megmutatkozott, a legnagyobb különbségek a 10-12, 12-14 és 14-16 óra között mutatkoztak. Ezt tünteti fel a 2. ábra.

A vizsgálat során súlyos mellékhatás nem fordult elő.

Egy másik hasonló összehasonlító clamp vizsgálat eredményeiről Bailey és mtsai számoltak be. ${ }^{15}$ Ez a vizsgálat - az előzőhöz hasonlóan - szintén randomizált, kettős vak, keresztezett elrendezésű euglykaemiás clamp vizsgálat volt, amelyben összesen két T1DM-es betegcsoport $(n=2 \times 24$ beteg) vett részt. A bevételi, illetve kizárási kritériumok is azonosak voltak az előző vizsgálatéval. Az első csoport betegei $0,4 \mathrm{NE} / \mathrm{tskg}$, a második csoport betegei 0,6 NE/tskg inzulint kaptak reggel 08.00kor (randomszerű besorolás szerint glargin-300 vagy degludek inzulint, majd a második periódusban ugyanilyen adagban az ellenkező készítményt). A két kezelési periódus között 8-26 napos kimosási fázist iktattak be, ezalatt a betegek a vizsgálatba besorolás előtti inzulinkezelést kapták. A vizsgálati fázisokban a betegek a bázisinzulin mellett naponta háromszor glulizint kaptak a fóétkezések előtt. Az utolsó étkezés a vizsgálat 7. napján este a vacsora volt, ekkor kapták a betegek az utolsó glulizin inzulint is. Ezután az 5,5 mmol/l cél-vércukorszint beállításához és stabilizálásához infúzióban glulizint vagy glukózt kaptak. 
A kezelés 8. napján, a clamp vizsgálat reggelén a betegek a leírt dózisú bázisinzulint (glargin-300 vagy degludek) kapták sc. Ettől kezdve 30 órán át a glukózinfúzióval tartották stabilan a cél-vércukorszintet $(5,5 \mathrm{mmol} / \mathrm{l})$.

Az inzulinhatás napon belüli variabilitását a GIR változása alapján ítélték meg. Az eredmények alapján a 0,4 NE/tskg dózist kapó csoportban a glargin-300 inzulin hatásának variabilitása 0,38 $\mathrm{mg} / \mathrm{min} / \mathrm{kg}$ volt, a degludek inzuliné $0,46 \mathrm{mg} / \mathrm{min} / \mathrm{kg}$, a GIR alapján számított arány 0,80 volt $(95 \%$-os CI: $0,66-0,96, p=0,047)$, vagyis a glargin-300 hatásának variabilitása szignifikánsan kisebbnek bizonyult. A 0,6 NE/tskg dózis mellett nem volt szignifikáns különbség a kétféle inzulin hatásának variabilitása között. ${ }^{16}$

A GIR görbe alatti területek összevetése révén $0,4 \mathrm{NE} / \mathrm{tskg}$ mellett $14 \%$-kal, míg 0,6 NE/tskg esetén $22 \%$ kal adódott kisebbnek a glargin-300 vércukorcsökkentő potenciálja a degludek potenciáljával szemben.

A fent ismertetett két tanulmány tehát - nem kis meglepetésre - ellentétes eredménnyel zárult: 0,4 $\mathrm{NE} / \mathrm{tskg}$ inzulin alkalmazása mellett az első vizsgálatban az inzulinhatás napon belüli variabilitása 37\%-kal volt kisebb a degludekkezelés mellett, a második vizsgálatban ugyanez $20 \%$-kal volt kisebb a glargin-300 inzulin kezelés mellett. Mindkét eredmény statisztikailag szignifikáns volt. Mindkét vizsgálat euglykaemiás clamp vizsgálat volt keresztezett elrendezésben (tehát ugyanaz a betegcsoport kapta az egyik, majd a másik inzulint kettős vak elosztással), a betegeket randomszerűen sorolták az egyes vizsgálati csoportokba. Ráadásul a két vizsgálat ugyanabban az intézetben történt.

A felsorolt azonosságok ellenére a két vizsgálat között számos különbség is volt, amelyek hozzájárulhattak az eltérő eredményekhez. ${ }^{16}$ Így pl. a két tanulmányban különböző töménységű degludek inzulint alkalmaztak: az elsőben $200 \mathrm{NE} / \mathrm{ml}$, míg a másodikban $100 \mathrm{NE} / \mathrm{ml}$ töménységü degludek inzulint. Ugyanakkor ez valószínűleg nem jelentett érdemi eltérést, mivel a két különböző koncentrációjú inzulinkészítmény bioekvivalenciája már korábban bizonyítást nyert egy célzott klinikai vizsgálatban. ${ }^{17}$ További különbség, hogy az első vizsgálatban a primer végpont a napok közötti (day-to-day) variabilitás meghatározása volt, szemben a második vizsgálattal, ahol a primer végpont a napon belüli (,within-day”) variabilitás, más kifejezéssel a „fluktuáció” mérése volt. Ezen kívül, az első tanulmányban este 08.00-kor, a második tanulmányban reggel 08.00-kor adagolták az inzulint a clamp napon, ami szintén növelheti a variabilitás eltéréseit, hiszen az esetleges hatásingadozások eltérő inzulinérzékenységű napszakokra estek.

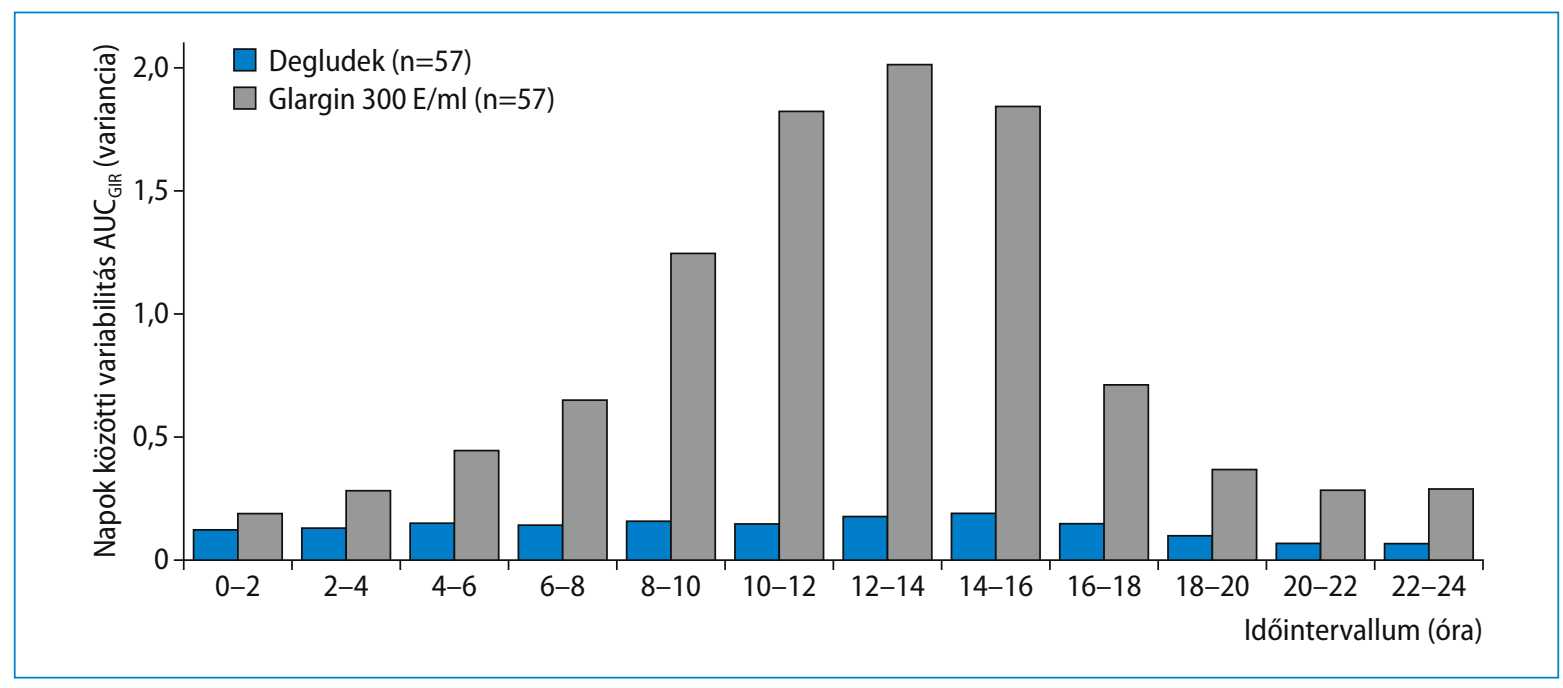

2. ábra. A degludek és a glargin-300 inzulinok hatásának napok közötti variabilitása. A glargin-300 inzulin variabilitása 3,7-szer (95\%-os Cl: 2,42-5,67, p<0,001) volt nagyobb, mint a degludek inzuliné 
Ugyanakkor a legfontosabb különbség minden bizonnyal az volt, hogy az első tanulmányban a napon belüli variabilitást a teljes napi glukózbevitel százalékában (azaz relatív GIR-variabilitásban) fejezték ki, míg a második vizsgálatban ugyanezt az infundált glukóz abszolút mennyiségével (mg/min/kg mértékegységben, azaz abszolút GIRvariabilitásban) tüntették fel. A relatív érték bevezetésére azért volt szükség, mert a két inzulin vércukorcsökkentő hatékonysága (potenciálja) nem azonos: az első vizsgálat adatai szerint a degludek 30\%-kal, a második szerint 14-22\%-kal erősebb vércukorcsökkentő potenciállal rendelkezik, mint a glargin-300.

Két inzulinkészítmény összevetésénél a mindennapi gyakorlatban valójában arra vagyunk kíváncsiak, hogy ugyanolyan mértékü vércukorcsökkentést milyen vércukoringadozás mellett sikerül elérni. Így nem kétséges, hogy amennyiben a két inzulinkészítmény jelentősen különböző vércukorcsökkentő hatással rendelkezik, úgy a napon belüli variabilitás számításánál valamiféle korrekcióra van szükség. A Heise-féle vizsgálatban számszerūen azonos (de nem ekvipotens) inzulindózisok mellett ezt a relatív GIR-variabilitás alkalmazásával oldották meg. A másik lehetséges megoldás ekvipotens (numerikusan eltérô) dózisok alkalmazása mellett az abszolút GIR-variabilitás mérése, ahogyan ez igényként a Bailey-féle cikk „discussion” fejezetében megfogalmazásra is kerül, és ezzel összefüggésben újabb vizsgálat szükségessége vetődik fel.

Ezen túl a napok közötti variabilitás tekintetében csak a Heise-féle vizsgálat szolgáltat adatot degludek vs. glargin-300 viszonylatban; eszerint a glukózcsökkentő hatás napok közötti variabilitása csaknem 4-szer kisebb degludekkezelés mellett a glargin-300-zal szemben.

\section{Hypoglykaemia a degludekkezelés mellett: prospektív klinikai tanulmányok}

$\mathrm{Az}$ inzulin vércukorcsökkentő hatásának kisebb variabilitása a hypoglykaemia gyakoriságának csökkenésével jár. Az alábbi IIIa és IIIb tanulmányokban elsősorban ezt a kérdést vizsgálták.

A degludek inzulinnal végzett nagyszámú korai klinikai tanulmány közül kiemelkednek a BEGIN vizsgálatok. ${ }^{18}$ A sorozat IIIa fázisú multicentrikus, randomizált, nyílt, célértékvezérelt prospektív tanulmányokból áll, amelyekben összesen 40 országból több mint 11 ezer beteg vett részt (ez volt a világon az addigi legnagyobb klinikai inzulinvizsgálati program, a részt vevő országok között szerepelt hazánk is). Három vizsgálatban 1-es típusú (T1DM, $\mathrm{n}=1110$ ), 6 vizsgálatban pedig 2-es típusú (T2DM, n=4709) betegek szerepeltek. A tanulmányokban vizsgálták a degludekkezelés mellett kialakuló hypoglykaemia gyakoriságát, a komparátor inzulin 7 tanulmányban glargin-100 volt. A BEGIN tanulmányokban hypoglykaemiának a $3,1 \mathrm{mmol} / \mathrm{l}$ alatti vércukorszintet tekintették (mivel ez az az értékhatár, ami már típusos tünetekkel jár, és ezt regisztrálják leggyakrabban a diabetológiai szakrendeléseken ellátott betegeink is). Ezt a glukózszinet ajánlotta az ADA (American Diabetes Association) és az EASD (European Association for the Study of Diabetes) is a közelmúltban publikált közös állásfoglalásban a hypoglykaemia „hivatalos” határértékének. ${ }^{19}$ A BEGIN vizsgálatokban az elfogadáshoz a hypoglykaemiát minden esetben vércukorméréssel is meg kellett erősíteni.

$\mathrm{Az}$ összehasonlító tanulmányokban fontos szempont volt, hogy a hypoglykaeemia gyakoriságának összevetésekor a kétféle inzulinnal (általában degludekkel és glargin-100-zal) kezelt betegcsoport azonos glykaemiás tartományba kerüljön, hiszen az összehasonlítás csak így reális. Ezért, a treat-to-target elvnek megfelelően ${ }^{20}$ a betegeket az inzulin napi adagjának feltitrálásával megfelelő anyagcsereegyensúlyi helyzetbe hozták (ez volt a vizsgálat ún. titrációs fázisa), majd az ekvilibráció elérése után az ún. fenntartó kezelési fázisban talált hypoglykaemia-gyakoriságokat vették figyelembe a statisztikai értékelésnél. Ezen kívül értékelték a teljes vizsgálati periódus hypoglykaemia-adatait is. A titrálási fázisban regisztrált hypoglykaemia-adatok önmagukban véve kevéssé informatívak, hiszen akkor még a napi inzulin dózisa folyamatosan változik.

A BEGIN tanulmányokban a kezelési alapszakaszok 26 vagy 52 hétig tartottak, de több esetben kiterjesztették a vizsgálatot 79, illetve 105 hétre is. A T2DM-en belül külön is értékelték azon betegcsoportok eredményeit, amelyek betegei korábban csak orális antidiabetikumot kaptak (ún. inzulinnaiv betegek), és csak a tanulmány idejére részesültek bazális inzulinszupplementációban (BOT terápia: basal insulin supplemented oral therapy). 
Értékelték természetesen a teljes T2DM-es és a teljes T1DM-es csoport hypoglykaemiás eseményeinek gyakoriságát is. Az eseményszámot 100 betegévre számították, és az így kapott hypoglykaemia-rátákat viszonyították egymáshoz.

Az összesített eredményeket a 3. ábrán foglaltuk össze. Amint látható, amikor az összes hypoglykaemia gyakoriságát analizálták, akkor mind az inzulin-naiv, mind a teljes T2DM-es csoportban szignifikánsan kevesebb hypoglykaemiát észleltek a degludek, mint a glargin-100 inzulin kezelés mellett, és ez egyaránt érvényes volt az alapszakaszban és a kiterjesztett kezelési fázisban észlelt hypoglykaemiás eseményekre is. A T1DM-es betegcsoportban viszont az összes hypoglykaemia gyakoriságában nem mutatkozott különbség a degludekkel, illetve a glargin-100-zal kezelt csoport eredményei között.

Amikor pedig a bázisinzulinra specifikusabban jellemző éjszakai hypoglykaemiák gyakoriságát külön analizálták, akkor mind az inzulin-naiv, mind a teljes T2DM-csoportban, mind pedig a teljes T1DM-csoportban szignifikánsan kisebb volt a hypoglykaemia-ráta a degludekkezelés mellett, és mindez egyaránt vonatkozott az alapszakaszban és a kiterjesztett időtartamban észlelt eseményekre. A BEGIN vizsgálatok tehát egyértelműen igazolták a degludekkezelés hypoglykaemia-előnyét a glargin-100 inzulin kezeléssel szemben. A degludek hypoglykaemia-előnye glargin-100-zal szemben a BEGIN vizsgálati programban hasonló (non-inferior) $\mathrm{HbA}_{1 c}$-csökkentés mellett, sőt nemritkán alacsonyabb éhomi vércukor kíséretében igazolódott.

Bár a BEGIN tanulmányok eredményei egyértelműen jelezték a degludekkezelés hypoglykaemia-előnyét a glargin-100 kezeléssel szemben, ezek az eredmények a randomizált-kontrollos tanulmányok tipikus, szelektált betegeire vonatkoztak. Kérdés maradt tehát, hogy ugyanez a kedvező hatás érvényesül-e, ha a fokozott hypoglykaemia-kockázatú betegek kizárása nélkül, az ún. „real-world” betegeken hasonlítjuk össze a hypoglykaemia gyakoriságát a kétféle kezelés mellett (azaz olyan betegeken, akikkel a mindennapi rutinmunka során a diabetológiai szakrendeléseken találkozunk). Ennek a kérdésnek a megválaszolására tervezték a SWITCH vizsgálatokat. A SWITCH 1 tanulmányban 501 1-es típusú, a

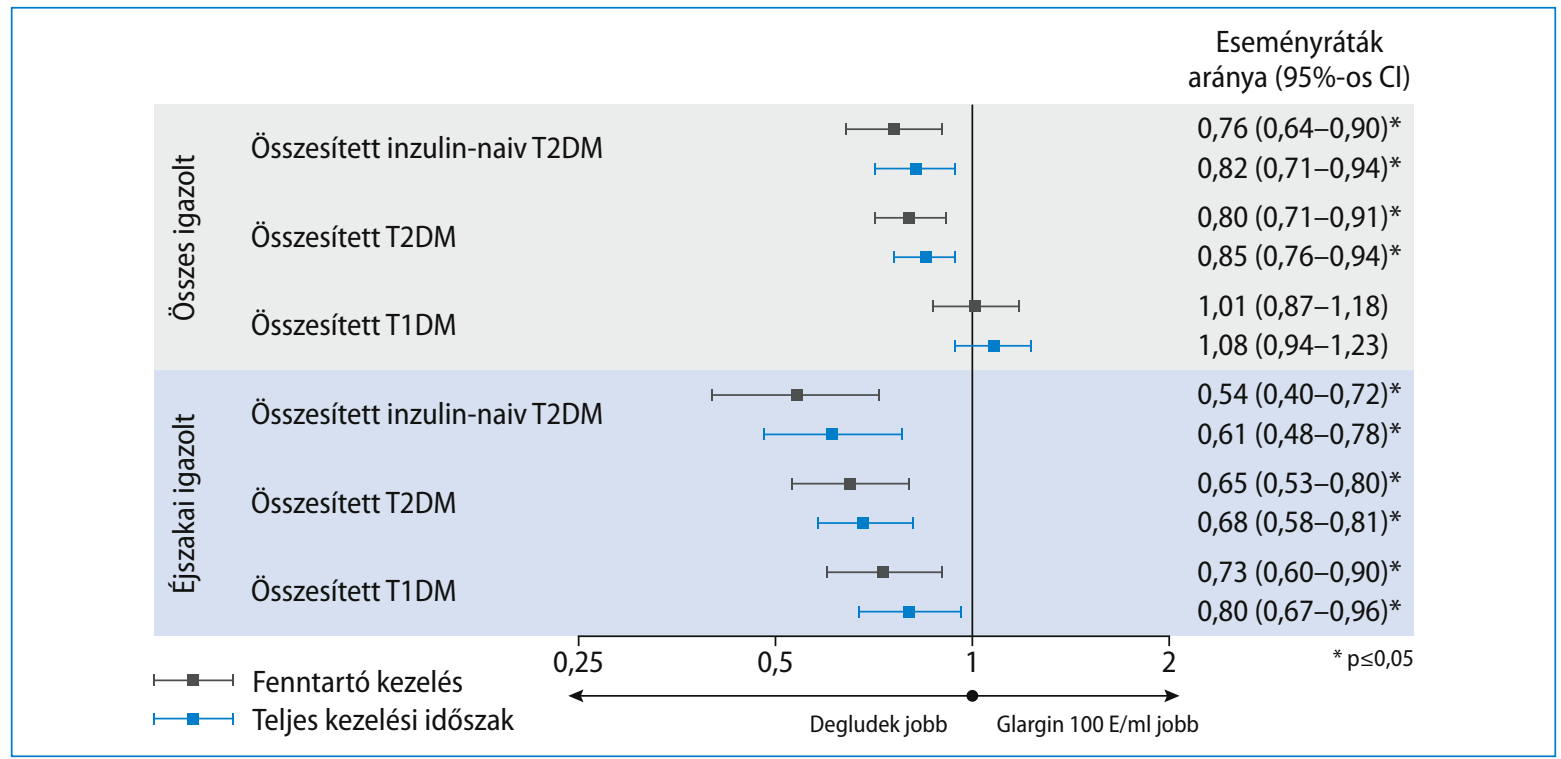

3. ábra. A BEGIN vizsgálatokban észlelt hypoglykaemiás epizódok gyakoriságának aránya, degludek vs. glargin-100 kezelés mellett. Az éjszakai, méréssel megerősitett hypoglykaemia szignifikánsan ritkábban fordult elő mind a T1DM-es, mind a T2DM-es betegekben, és az összes hypoglykaemia szignifikánsan ritkább volt a T2DM-es betegekben a degludekkezelés mellett 
SWITCH 2 vizsgálatban pedig 720 2-es típusú cukorbetegen követték, hogy a degludek inzulin kezelés mellett kevesebb-e a hypoglykaemia, mint a glargin-100 kezelés mellett.

A SWITCH vizsgálatok hypoglykaemia-fókuszú tanulmányok voltak, azaz eltérően számos más inzulinvizsgálattól a hypoglykaemia előfordulását mint elsődleges végpontot tanulmányozták; így jóval nagyobb statisztikai erőre lehetett számítani a kérdés megválaszolásában. A SWITCH programban a betegbesorolás szempontjai több ponton eltértek attól, amit a BEGIN vizsgálatokban (és általában az inzulinokkal végzett randomizált-kontrollos vizsgálatokban) alkalmaztak. Ezek közül ki kell emelnünk, hogy amíg a „szokásos” inzulinvizsgálatokból általában kizáró tényező volt a fokozott hypoglykaemia-hajlam, addig a SWITCH vizsgálatokban a besorolás feltétele volt a legalább egy hypoglykaemiára hajlamosító kockázati tényező megléte (mint pl. hypoglykaemiás epizód az elmúlt 12 hétben, közepesen beszűkült vesefunkció [eGFR 30-59 ml/min/testfelület], a hypoglykaemia megérzésének hiánya vagy legalább 1 súlyos - külső segítséget igénylő - hypoglykaemiás rosszullét az elmúlt évben). Mindkét SWITCH vizsgálat randomizált prospektív vizsgálat volt, kifejezetten magas evidenciaszintű tanulmányokról van szó.

A SWITCH 1 vizsgálat $2 \times 32$ héten át folyt, keresztezett kezelési elrendezésben. Az induláskor a betegeket randomszerüen vagy a degludek, vagy a glargin-100 kezelési csoportba sorolták. Harminckét hetes kezelés után váltás történt a másik inzulinra, a váltáskor a napi inzulin dózisát 20\%kal csökkentették, majd az éhomi vércukorszintek alapján fokozatosan, hetek alatt titrálták fel az inzulint a megfelelő napi adagra. Mindkét 32 hetes periódusban az első 16 hét a titrálást, a második 16 hét a fenntartó kezelést jelentette. Fontos megerősítenünk, hogy a statisztikai értékelésbe itt is elsődlegesen a fenntartó kezelés fázisában észlelt eseményeket számították be, amikor az inzulin dózisa már stabil volt, tehát a betegek - a fent említett treat-to-target elvnek megfelelően - mindkét kezelési csoportban az előre kitűzött (és azonos) glykaemiás tartományban voltak.

Vizsgálták a fenntartó kezelés során észlelt öszszes, tünetekkel járó és méréssel is megerősített hypoglykaemiát (vércukor $<3,1 \mathrm{mmol} / \mathrm{l}$ ). Ezen kívül külön értékelték az éjszakai hypoglykaemiák arányát is, valamint regisztrálták a súlyos hypoglykaemiákat is, ezek elfogadásáról független szakmai bizottság döntött.

$\mathrm{Az}$ eredményeket a 4. ábrán foglaltuk össze. Amint az ábra adataiból kitűnik, a T1DM-es betegek között mind az összes tünetes, mind az éjszakai tünetes, mind pedig a súlyos hypoglykaemiák aránya szignifikánsan kisebb volt a degludekkezelés mellett a fenntartó kezelési időszakban. Az öszszes tünetes hypoglykaemiára vonatkozó (degludek vs. glargin-100) rátaaránya 0,89 volt $(95 \%$-os CI: $0,85-0,94$, ezek alapján $\mathrm{p}<0,001$ a non-inferioritásra és p<0,001 a degludek szuperioritására vonatkozóan). Kiemelendő még, hogy a bázisinzulinokra specifikusabb markerként jellemző éjszakai tünetes hypoglykaemia 36\%-kal ritkábban fordult elő a degludek ágon (becsült rátaarány 0,64; 95\%-os CI: $0,56-0,73, \mathrm{p}<0,001$ a non-inferioritásra és $\mathrm{p}<0,001$ a degludek szuperioritására), továbbá a legnagyobb veszélyt jelentő súlyos hypoglykaemia is $35 \%$-kal ritkábban fordult elő a degludek ágon (becsült rátaarány 0,$65 ; 95 \%$-os CI: $0,48-0,89, \mathrm{p}=0,007)$.

Összességében elmondható, hogy a SWITCH 1 vizsgálatban, érdemi hypoglykaemia-kockázattal bíró T1DM-es betegekben a degludek inzulin kezelés szignifikánsan csökkentette a tünetekkel járó összes, valamint az éjszakai és a súlyos hypoglykaemia gyakoriságát a glargin-100 inzulin kezeléssel szemben. Az eredmények igazolták, hogy a degludekkezelés a hypoglykaemia-kockázat csökkentése szempontjából nem csak non-inferior, hanem szuperior is a glargin-100 inzulinnal szemben, és ez egyaránt vonatkozott az összes, az éjszakai és a súlyos hypoglykaemiákra. Ezenkívül, a degludekkezelés, átlagosan 3\%-kal kisebb napi dózisban azonos $\mathrm{HbA}_{1 \mathrm{c}}$-szintet és valamivel alacsonyabb éhomi vércukorszintet biztosított a 64 hetes vizsgálat végére. ${ }^{21}$

A SWITCH 2 vizsgálat a SWITCH 1-hez hasonló felépítésű volt. Ebben a randomizált, kettős vak, keresztezett elrendezésű, tanulmányban 721 T2DM-es betegen hasonlították össze a degludek és a glargin-100 inzulin kezelés mellett a hypoglykaemiás epizódok gyakoriságát. A betegek besorolási feltételei azonosak voltak a SWITCH 1 vizsgálatéval: itt is feltétel volt a legalább egy hypoglykaemiára hajlamosító tényező, a vizsgálat keresztezett elrendezésű volt, $2 \times 32$ hétig tartott, mindkét periódusban 16 hét volt a titrálási és 16 hét a fenntartó kezelési szakasz. A besorolt 
betegek átlagos életkora 62 év volt, testtömegindexük $<45 \mathrm{~kg} / \mathrm{m}^{2}, \mathrm{HbA}_{1 \mathrm{c}}$-szintjük $<9,5 \%$ volt. A tanulmányban a fenntartó kezelési periódusban észlelt hypoglykaemiás eseményeket (összes, éjszakai és súlyos hypoglykaemia) értékelték. A kiemelten magas evidenciaszint tehát erre a tanulmányra vonatkozóan is igaz volt.

A T2DM-csoportban mind az összes, mind az éjszakai hypoglykaemia szignifikánsan kevesebb volt a degludekkezelési ágon a fenntartó kezelési időszakban. Az összes tünetes hypoglykaemiára vonatkozó (degludek vs. glargin-100) rátaarány 0,70 volt (95\%-os CI: 0,61-0,80, p<0,001). Az éjszakai tünetes hypoglykaemia 42\%-kal ritkábban fordult elő a degludek ágon (becsült rátaarány 0,58; 95\%os CI: $0,46-0,74, p<0,001)$, emellett a súlyos hypoglykaemia előfordulása is numerikusan kisebb volt a fenntartó kezelési szakaszban, de a kis eseményszám miatt ez nem bizonyult szignifikánsnak (becsült rátaarány 0,54; 95\%-os CI: 0,21-1,43, $\mathrm{p}=0,35)$.Ugyanakkor a teljes 32 hetes kezelési periódusra nézve a nagyobb eseményszám miatt már statisztikailag szignifikánsan, 51\%-kal kevesebb volt a súlyos hypoglykaemia a degludek ágon, mint a glargin-100 kezelés mellet (becsült rátaarány 0,49; 95\%-os CI: 0,26-0,94, p=0,03) (4. ábra).

Az egyéb kimeneti paraméterek $\left(\mathrm{HbA}_{1 \mathrm{c}}\right.$, éhomi vércukorszint, testsúly) nem különböztek szignifikánsan a kétféle kezelés mellett. A napi inzulinigény 4\%-kal volt kisebb a degludek inzulinnal kezelt csoportban $(\mathrm{p}<0,001)$. A $\mathrm{HbA}_{1 \mathrm{c}}$-szint csökkentése tekintetében a degludek non-inferioritása igazolódott a glargin-100 inzulin kezeléssel szemben. Nem volt különbség az adverz események gyakoriságában sem a kétféle inzulinkezelés között. ${ }^{22}$

Egy post hoc analízis szerint a vércukorszint, illetve a $\mathrm{HbA}_{1 c}$-szint ugyanazon mértékű csökkenése glargin-100 kezelés mellett a hypoglykaemiák számának nagyobb arányú növekedésével járt, mint degludekkezelés mellett: $1 \%$-os $\mathrm{HbA}_{1 c^{-}}$ szint-csökkenés T1DM-es betegek körében a glargin-100 ágon 34\%-kal, a degludek ágon 18\%-kal növelte a hypoglykaemia-rátát. Ugyanez a T2DMes betegek között $67 \%$, illetve $45 \%$ volt.

Összefoglalva mindkét vizsgálatot, azt a következtetést vonhatjuk le, hogy a legalább egy hypoglykaemiás kockázati tényezővel rendelkező 1-es és 2-es típusú diabeteses betegekben a degludek inzulin klinikailag jelentősen (és statisztikailag is szignifikánsan) csökkentette a hypoglykaemia előfordulásának gyakoriságát. A biometriai analízis szerint a degludek nem csak non-inferiornak, hanem a hypoglykaemia gyakoriságának szempontjából szuperiornak is bizonyult a $100 \mathrm{E} / \mathrm{ml}$ töménységű glargin inzulinnal szemben.

(Érdemes még megemlíteni, hogy a hypoglykaemia gyakoriságának csökkenése a SWITCH vizsgálatokban gyakorlatilag azonos mértékű volt azzal,

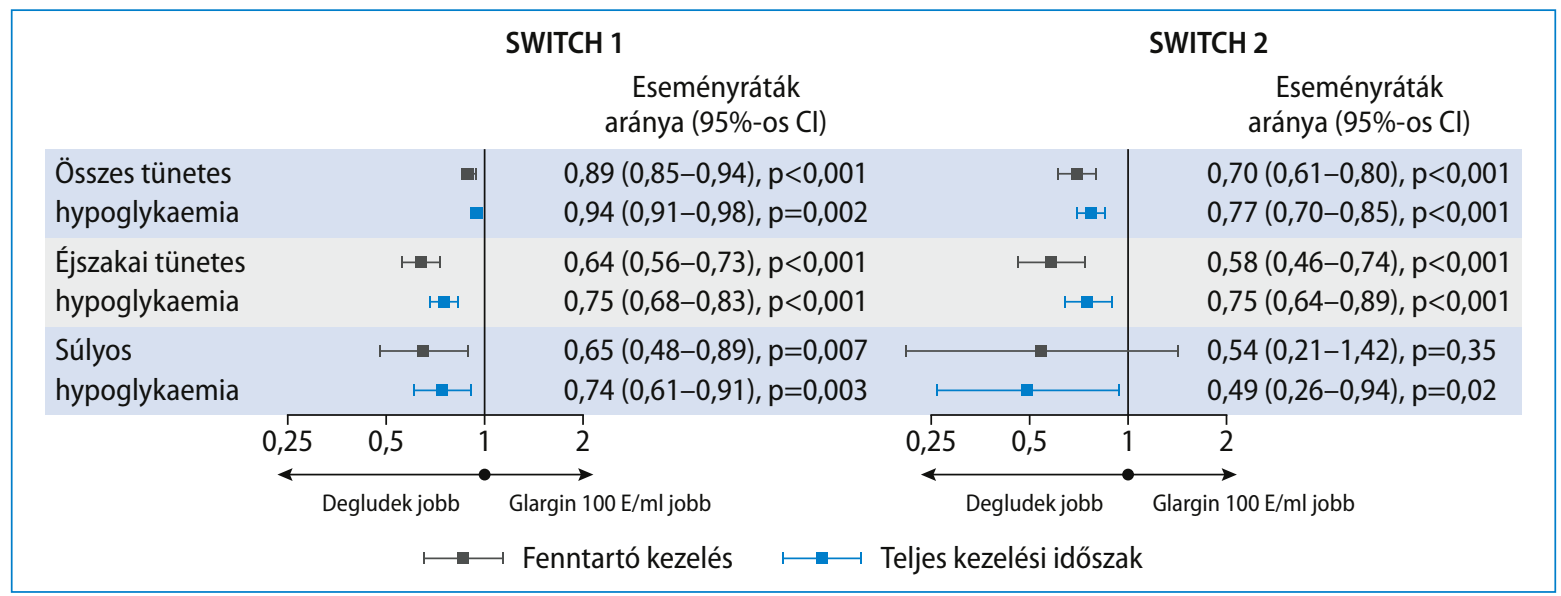

4. ábra. A hypoglykaemiás epizódok (eseményráták aránya) a SWITCH vizsgálatokban. A T1DM-es betegekben az összes és az éjszakai tünetes, valamint a súlyos epizódok, a T2DM-es betegekben pedig az összes és az éjszakai tünetes epizódok szignifikánsan ritkábban fordultak elő a degludek, mint a glargin-100 kezelés mellett 
mint amit 8-10 évvel korábban észleltek, amikor az újonnan bevezetett glargin és detemir inzulinok hypoglykaemia-csökkentő hatását vizsgálták az NPH bázisinzulinokkal szemben).

A degludekkezelés hypoglykaemia-előnyét megerősítette a 2017-ben közölt DEVOTE tanulmány is. Ennek a tanulmánynak az alapvető célja a degludek inzulin kardiovaszkuláris biztonságosságának igazolása volt. Ebbe a randomizált, kontrollos, kettős vak vizsgálatba összesen 7637 T2DM-es beteget vontak be, a betegek az aktív ágon degludek, a kontroll ágon glargin-100 inzulin kezelésben részesültek a standard antidiabetikus terápia mellett.

A vizsgálat treat-to-target felépítésű, eseményvezérelt vizsgálat volt. Beválasztási feltétel volt 50 év felett a legalább 1 kardiovaszkuláris (CV) vagy renális betegség, 60 év felett csak a legalább $1 \mathrm{CV}$ kockázati tényező. Ugyancsak feltétel volt a 7\%os vagy azt meghaladó $\mathrm{HbA}_{1 \mathrm{c}}$-szint (7\% alatt csak akkor soroltak be beteget, ha az naponta legalább 20 NE bázisinzulin-kezelésben részesült). A bázisinzulint a betegek naponta 1-szer, az esti órákban kapták. A dózist az eredeti útmutatás szerint úgy titrálták fel, hogy a reggeli előtt mért éhomi vércukorszint 4,0-5,0 mmol/l közé kerüljön, ugyanakkor a vizsgálat során bevezettek egy alternatív titrálási lehetőséget 5-7 mmol/l közötti éhomi célértékkel.

A tanulmány primer végpontja a $\mathrm{CV}$ halál, a nem halálos kimenetelű szívinfarktus vagy stroke volt. A CV végpontokat független szakmai bizottság értékelte. Másodlagos végpontként regisztrálták a súlyos hypoglykaemiás események gyakoriságát. További végpontként szerepelt még az angina miatti kórházi felvétel, az éhomi vércukorszint és a $\mathrm{HbA}_{1 \mathrm{c}}$-szint változása, a testsúly, a GFR, a vérnyomás és a lipidszintek változása is. A vizsgálat közel 2 évig tartott.

A primer végpont 325 betegen $(8,5 \%)$ fordult elő a degludekkel kezelt, és 356 betegen $(9,3 \%)$ a glargin-100 inzulinnal kezelt csoportban. A számított kockázati arány 0,91 (95\%-os CI: 0,78-1,06), ezek alapján $\mathrm{p}<0,0001$ a non-inferioritásra nézve. A CV halálozásban sem volt különbség a két csoport között: $5,3 \%$ vs. $5,8 \%$ (HR: 0,91, 95\%-os CI: $0,76-1,11, p=0,35)$. A CV események szempontjából tehát a degludek non-inferiornak bizonyult a glargin-100 inzulinnal szemben. A 24. hónapban a $\mathrm{HbA}_{1 \mathrm{c}}$ szintje azonos volt a két csoportban. $\mathrm{Az}$ éhomi vércukorszint viszont szignifikánsan alacsonyabb volt a degludek inzulin kezelés mellett: $7,11 \pm 3$ vs. $7,55 \pm 3 \mathrm{mmol} / \mathrm{l}(\mathrm{p}<0,001)$.

A hypoglykaemia gyakoriságában korábban leírt különbség (a degludek javára) ebben a tanulmányban is megmutatkozott: bár a $\mathrm{HbA}_{1 \mathrm{c}}$ azonos, az éhomi vércukorszint pedig szignifikánsan alacsonyabb volt a degludekkezelési ágon, a súlyos hypoglykaemia gyakorisága statisztikailag szignifikánsan kisebb volt a degludekkel kezelt csoportban: a hypoglykaemia-ráta aránya 0,60 (95\%-os CI: $0,48-0,76, p<0,001)$ a degludek szuperioritására vonatkozóan (a glargin-100 kezeléssel szemben). Még ennél is nagyobb mértékü, 53\%-os csökkenést észleltek a degludek ágon az éjszakai súlyos hypoglykaemiák gyakoriságában (kockázat: 0,47; 95\%-os CI: 0,31-0,73, p<0,001 a glargin-100 kezeléssel szemben) (5. ábra).

Nem volt érdemi különbség a két csoport között a napi inzulindózisban, valamint az adverz események arányában sem. Összefoglalóan azt mondhatjuk, hogy a DEVOTE vizsgálat egyrészt igazolta, hogy a degludek inzulin a CV kockázat szempontjából non-inferior a glargin-100 inzulinnal szemben, másrészt megerősítette a BEGIN és a SWITCH 2 vizsgálat eredményeit, miszerint T2DM-es betegekben a degludekkezelés mellett szignifikánsan kisebb a súlyos és az éjszakai súlyos hypoglykaemiák gyakorisága, mint a glargin-100 inzulin kezelés mellett. ${ }^{23}$

\section{Degludek és glargin-300 inzulint direkt összehasonlító (head-to-head) klinikai vizsgálatok}

Egy, a közelmúltban publikált tanulmányban (BRIGHT vizsgálat) a szerzők a glargin-300 és a degludek inzulin hatékonyságát és biztonságosságát hasonlították össze. ${ }^{24} \mathrm{~A}$ BRIGHT vizsgálat egy 24 hetes nyílt, head-to-head, randomizált, aktív kontrollos, kétágú, parallel vizsgálat volt. A besorolt betegek OAD-vel már nem megfelelően kontrollált, de inzulinnal még nem kezelt 2-es típusú diabeteses betegek voltak, akiket véletlenszerűen soroltak glargin-300 $(n=466)$ vagy degludek $(100$ $\mathrm{E} / \mathrm{ml})(\mathrm{n}=463)$ kezelési csoportba. A vizsgálatban 16 ország 158 diabetológiai centruma vett részt. A betegeknek a két bázisinzulint az esti órákban, lefekvés előtt adagolták. A napi inzulindózist úgy 
titrálták fel, hogy a betegek otthoni mérései szerint a reggeli éhomi vércukorszint 4,4-5,6 mmol/1 közé kerüljön. A vizsgált végpontok többek között a $\mathrm{HbA}_{1 \mathrm{c}}$ és az éhomi vércukorszint változása a kiindulástól a 12. és 24 . hétig, a hypoglykaemia gyakorisága (eseményráta) és a hypoglykaemiát elszenvedő betegek aránya (esemény incidenciája) a vizsgálat teljes 24 hetében, illetve az egyes (titrálási és fenntartó) kezelési szakaszokban, valamint az adverz események gyakorisága volt. A 24 hetes vizsgálat első 12 hetében történt a dózistitrálás és a második 12 hét volt a fenntartó kezelési fázis.

A kiindulási glykaemiás paraméterek a következőképpen alakultak: a kiindulási $\mathrm{HbA}_{1 \mathrm{c}}$ a glargin-300 ágon 8,71\%, a degludek ágon 8,57\% volt; a laboratóriumban mért kiindulási éhomi vércukorszint a glargin-300 ágon 10,6 mmol/l, a degludek ágon $10,1 \mathrm{mmol} / \mathrm{l}$ volt. A 24 . hétre a $\mathrm{HbA}_{1 \mathrm{c}}$ hasonló mértékben csökkent a glargin-300 és a degludek inzulin kezelési csoportban, elérve a 7,03\% értéket, ami a glargin-300 inzulin non-inferioritását igazolja a degludekkel szemben a $\mathrm{HbA}_{1 \mathrm{c}}$-csökkentés tekintetében a teljes vizsgálati időszakra vonatkozólag. A laboratóriumban mért éhomi vércukorszint szignifikánsan, 0,43 mmol/l-rel nagyobb mértékben csökkent a degludek ágon a vizsgálat 24. hetére, tovább növelvén az indulásnál rögzített $0,5 \mathrm{mmol} / \mathrm{l}$-es $(10,1 \mathrm{mmol} / \mathrm{l}$ vs. $10,6 \mathrm{mmol} / \mathrm{l}) \mathrm{kün}-$ lönbséget a glargin-300 inzulinhoz képest. Ugyanakkor - érdekes módon - az önellenőrzéssel mért éhomi vércukorszint csökkenésében nem mutatkozott érdemi különbség a két kezelési ág között.

A biztonságosság tekintetében elősorban a hypoglykaemia-kockázatot értékelték. Az első 12 héten (tehát a titrálási periódusban) a glargin-300 kezelés mellett szignifikánsan kevesebb volt a hypoglykaemia a glargin-300 kezelési ágon: a betegek saját, otthoni mérései alapján a 3,0 mmol/l küszöbértéket figyelembe véve a hypoglykaemia-incidencia 37\%-kal volt alacsonyabb (OR: 0,63; 95\%-os CI: $0,40-0,99, p=0,044)$, az eseményráta pedig 43\%kal volt kisebb (RR: 0,57; 95\%-os CI: 0,34-0,97, $\mathrm{p}=0,038)$ a glargin-300 kezelés mellett. A 3,9 $\mathrm{mmol} / \mathrm{l}$ alatti vércukorértéket tekintve a hypoglykaemia-incidencia 26\%-kal (OR: 0,74; 95\%-os CI: $0,57-0,97, \mathrm{p}=0,030)$, az eseményráta $23 \%$-kal (RR: 0,77; 95\%-os CI: $0,62-0,96, p=0,023)$ volt alacsonyabb a glargin-300 kezelés mellett. Az éjszakai hypoglykaemiákat tekintve a titrálási időszakban a 3,9 mmol/l küszöbértéket alapul véve az éjszakai

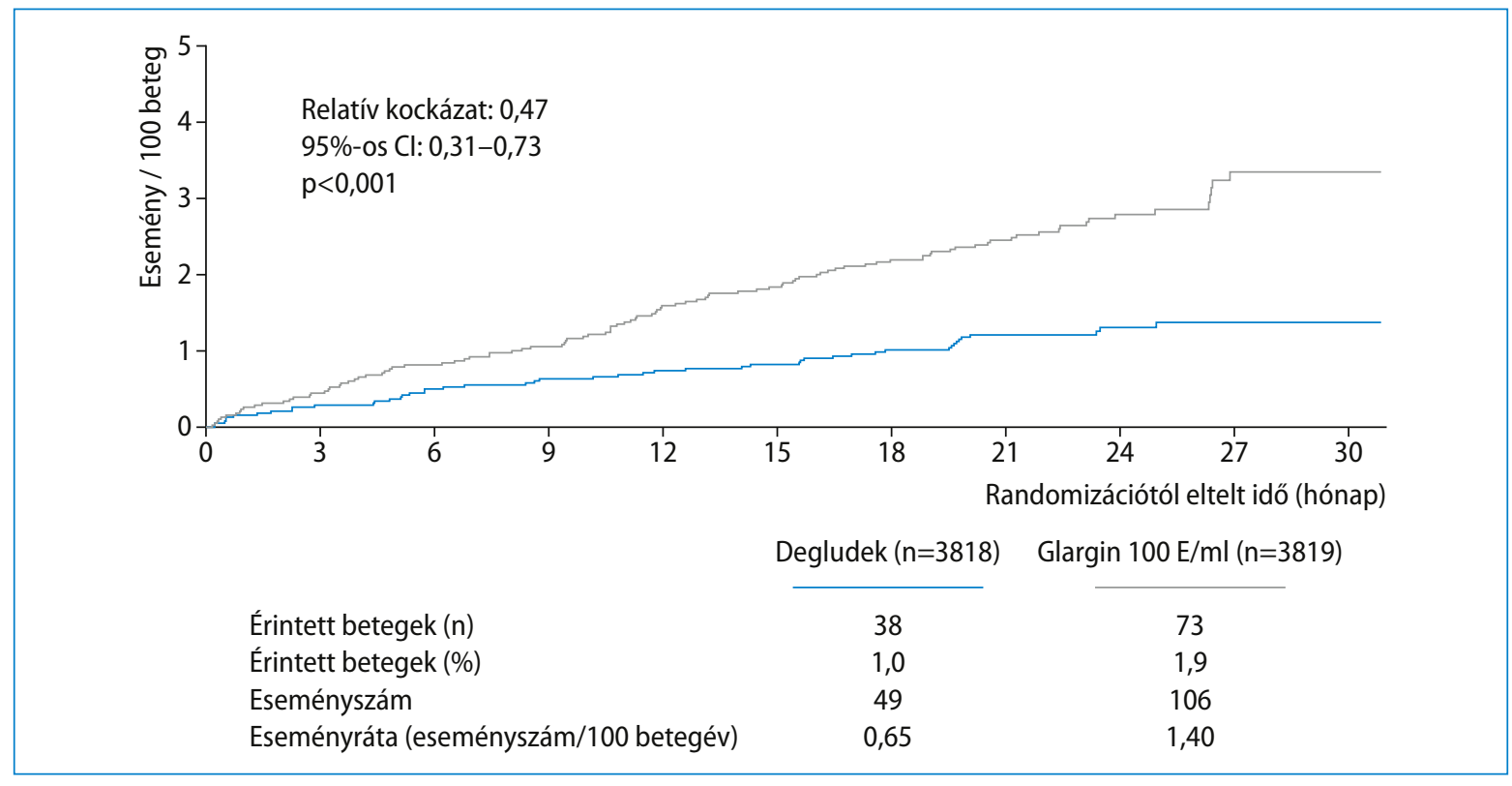

5. ábra. Az éjszakai súlyos hypoglykaemia kockázatának csökkenése a DEVOTE tanulmányban, degludek vs. glargin-100 inzulin 
hypoglykaemia-ráta szignifikánsan $(\mathrm{p}=0,040)$ alacsonyabb volt a glargin-300 kezelés mellett, míg a másik három éjszakai hypoglykaemia-paraméterben (a két küszöbértéket, valamint incidenciát és rátát tekintve) nem mutatkozott érdemi különbség a két kezelési ág között. Ugyanakkor meg kell említeni, hogy az éhomi vércukorszintek alacsonyabbak voltak a degludekkezelés mellett. Emellett a hypoglykaemia-incidencia és -eseményráta sem a fenntartó kezelési periódusban, sem a teljes 24 hetes vizsgálati időszakban nem különbözött a kétféle kezelési csoportban, akár az összes, akár az éjszakai hypoglykaemiákat értékelték.

Figyelembe véve a jelen összefoglaló közleményben már korábban leírt szempontokat, a hypoglykaemia gyakoriságának eltérései két különböző inzulinnal végzett kezelés mellett érdemben csak a fenntartó kezelés időszakában vehetők figyelembe, és ezen adatok statisztikai értékelése a leginkább informatív. Tekintetbe véve, hogy a jelen vizsgálatban kizárólag a titrálási fázisban volt különbség a két inzulin között, de sem a fenntartó kezelési fázisban, sem a teljes vizsgálati periódusban nem, a leírt eredmények további megerősítést igényelnek.

Egy másik jelentős vizsgálat a CONFIRM vizsgálat volt, egy beavatkozással nem járó retrospektív tanulmány, amelyben a degludek inzulin hatékonyságát vetették össze a glargin-300 inzulin hatékonyságával. A betegek egy nagy amerikai egészségügyi adatbázisból (Explorys; IBM Watson Health $^{\mathrm{TM}}$ ) kerültek beválasztásra, amely több mint 50 millió beteg egészségügyi adatait tartalmazza elektronikusan. A beválasztásnál propensity score alapú illesztést alkalmaztak a két kezelési csoport komparabilitásának biztosítására. A tanulmányba 4056 T2DM-es beteget soroltak be, akiket fele-fele arányban degludek, illetve glargin-300 inzulinnal kezeltek (tehát 2028 beteget mindkét csoportba). A betegek bázisinzulint korábban nem kaptak, viszont anyagcseréjük már OAD- vagy GLP-1-RAkezeléssel nem volt egyensúlyban. Az értékelés során alapvetően az inzulinkezelés megkezdése utáni 6 hónapra fókuszáltak, de a perzisztencia felmérése céljából 2 évre terjedt ki az adatgyűjtés. A kiindulási $\mathrm{HbA}_{1 \mathrm{c}}$-adatot az inzulinkezelés megkezdése előtti 90 napban mért $\mathrm{HbA}_{1 c}$-érték alapján adták meg, míg a kezelésvégi $\mathrm{HbA}_{\mathrm{cc}}$-t a 6 hónapos inzulinkezelési időszak második 90 napjában mért $\mathrm{HbA}_{1 \mathrm{c}}$-érték alapján. A hypoglykaemiás eseményeket az adatbázisban rögzített megfelelő BNO-kódok alapján gyüjtötték össze.

Hat hónapos inzulinkezelés után a $\mathrm{HbA}_{1 \mathrm{c}}$-szint $1,5 \%$-kal csökkent a degludek és $1,2 \%$-kal a glargin-300 kezelés mellett, a 0,3\%-os különbség statisztikailag szignifikánsnak bizonyult (ETD: $-0,3$; 95\%-os CI: $-0,51--0,03, p=0,03)$. A hypoglykaemia-ráta $30 \%$-kal volt alacsonyabb a degludekkel kezelt betegek között (RR: 0,70; 95\%-os CI: $0,50-0,99, \mathrm{p}<0,05)$, a legalább egy hypoglykaemiát elszenvedő betegek aránya pedig 36\%-kal volt kisebb a degludek ágon (OR: 0,64; CI: 0,47-0,88, $\mathrm{p}<0,01)$. Hat hónap kezelés után a felírt inzulindózisok a degludek ágon 9\%-kal kisebbek voltak, mint a glargin-300 mellett $(p=0,04)$. Érdekes megfigyelés volt még, hogy a betegeket 2 éven át követve glargin-300 kezelés mellett 37\%-kal volt több a terápiát elhagyók száma, mint a degludekkezelés mellett $(\mathrm{p}<0,001)$. Bár a degludek inzulin kezelés melletti, szignifikánsan magasabb terápiahüség oka pontosan nem tisztázott, abban a kevesebb hypoglykaemia mellett a hosszabb hatástartam által biztosított nagyobb flexibilitásnak is fontos szerepe lehet. ${ }^{25}$ Összességében tehát a degludek kisebb inzulindózis alkalmazásával, alacsonyabb hypoglykaemia-kockázat mellett és nagyobb mértékủ terápiamegtartással biztosított jobb glykaemiás kontrollt a glargin-300 E/ml inzulinnal szemben 2-es típusú diabeteses betegekben. ${ }^{26}$

A degludek vs. glargin-300 összehasonlítás vonatkozásában még további randomizált, kontrollos vizsgálati eredményekre lehet számítani a közeljövőben, amelyek remélhetőleg magas evidenciaszint mellett lesznek képesek választ adni a kérdésre.

\section{Az eredmények összefoglalása, terápiás következtetések}

A degludek a jelenleg elérhető bázisanalóg-készítmények közül a leghosszabb hatástartamú, kifejezetten egyenletes hatású inzulin. Az egyenletes és elnyújtott hatást a teljesen újszerủ kémiai szerkezet, a következményes multihexamer-képződés és az egyenletes felszívódás teszi lehetővé. A molekula acilálása fokozza az albuminhoz való kötődést, emiatt a vérben a degludek $98 \%$ a albuminhoz kötődik, és a receptorok szabaddá válásakor az albuminról leválva jut a receptorra. 
Az inzulinreceptorok egyenletes telítődését így az albumin pufferoló hatása biztosítja.

Clamp vizsgálatokkal a degludek hatásának variabilitása mind a napon belüli, mind az egymás utáni napokon minimálisnak bizonyult. Egy vizsgálatsorozatban a napon belüli variabilitás 4-szer volt kisebb, mint a glargin-100 inzulin variabilitása. A glargin-300-zal összevetve, ha a variabilitást relatív GIR-értékekben számították, akkor a degludek napon belüli variabilitása szignifikánsan kisebbnek adódott a glargin-300 inzulin hatásának variabilitásánál.

A hypoglykaemiás események (összes, éjszakai, súlyos és éjszakai súlyos epizódok) gyakorisága magas evidenciaszintű vizsgálatokban, így a BEGIN, a SWITCH 1 és 2, valamint a DEVOTE tanulmányokban egyaránt szignifikánsan kisebbnek bizonyult a degludek, mint a glargin-100 inzulin kezelés során. Emellett a DEVOTE vizsgálat a degludek inzulin CV biztonságosságát (non-inferioritását) is bizonyította a glargin-100 inzulinnal szemben.

A glargin-300 és a degludek inzulinok összehasonlítása céljából több vizsgálatot végeztek. A BRIGHT vizsgálat titrálási fázisában ugyan előny mutatkozott a glargin-300 javára a hypoglykaemia-kockázat tekintetében, de ekkor még az inzulin napi adagja folyamatosan változott. A hypoglykaemiák gyakorisága a fenntartó kezelési, valamint a teljes kezelési fázisban nem különbözött szignifikánsan a kétféle kezelés mellett. A CONFIRM obszervációs vizsgálatban a degludek inzulin kezelés $\mathrm{HbA}_{1 \mathrm{c}}$-szint nagyobb csökkenését, ugyanakkor 30\%-kal kevesebb hypoglykaemiát igazolt a glargin-300 inzulin kezeléssel szemben. Egyúttal a glargin-300 terápia mellett 37\%-kal több volt a terápiát elhagyók száma kétéves távon $(\mathrm{p}<0,001)$. A kérdés tisztázására további randomizált, prospektív vizsgálat folyamatban van.

Hangsúlyozni kell ugyanakkor, hogy a degludekkezelésnek feltehetően nem csak aktuális, rövid távú előnyei vannak. A kisebb glukózvariabilitás eredményeként a degludekkel kezelt betegek vércukra a közel-normális tartományban stabilizálható, a hypoglykaemia gyakoriságának növekedése nélkül. A hosszú távú jó beállításnak pedig jelentős vascularis előnyei lehetnek - amint arra a múlt nagy betegszámú követéses vizsgálatai felhívták a figyelmet.

A DCCT tanulmányban T1DM-es betegeken a 6,5 éves intenzív inzulinkezelés mellett a microvascularis szövődmények jelentős, 35-76\%os, statisztikailag szignifikáns csökkenését figyelték meg a konvencionális kezeléssel szemben. A $\mathrm{HbA}_{1 \mathrm{c}}$ mintegy $2 \%$-kal volt alacsonyabb az intenzíven kezelt csoportban. Az egyetlen hátrány a 3-szosra nőtt hypoglykaemia-gyakoriság volt. ${ }^{27}$ Bő 10 éves további követés után (DCCT/EDIC), amikor már a $\mathrm{HbA}_{1 \mathrm{c}}$-szintbeli különbség a tizedére csökkent (7,9\% vs. $8,1 \%)$, az intenzív kezelés microvascularis szövődményekre kifejtett előnyös hatása még mindig változatlanul kimutatható volt, és ugyanakkor már a macrovascularis szövődmények terén is jelentős előnyöket lehetett igazolni. ${ }^{28}$ A nemrégen publikált 30 éves megfigyelés eredményei a CV szövődmények szignifikáns csökkenését igazolták, mindezt - legalábbis részben - az egykori, 6,5 éves intenzív kezelés és a jobb vércukorszint eredményeként (metabolikus memória). ${ }^{25}$

Hasonló előnyöket figyeltek meg T2DM-es betegekben is a UKPDS vizsgálatban. Az intenzív inzulinkezelés, a $0,9 \%$-kal alacsonyabb $\mathrm{HbA}_{1 \mathrm{c}}$-szint az első 10 év után a microvascularis szövődmények szignifikáns csökkenését váltotta ki. ${ }^{29}$ További 10 év múlva - már aktuális intenzív kezelés nélkül is mind a micro-, mind a macrovascularis szövődmények tartós csökkenését regisztrálták. ${ }^{30} \mathrm{Az}$ időben elkezdett intenzívebb kezelés, a stabil közel-normoglykaemiás állapot tehát a diabetes félelmetes késői vascularis szövődményeinek csökkenését eredményezheti.

Az eredmények szerint a degludek inzulin kezeléssel a betegek számára közel-normoglykaemiás, egyenletes vércukorszint biztosítható a hypoglykaemia gyakoriságának lényeges növekedése nélkül. Jövőbeli, hosszú távú követéses vizsgálatok szükségesek annak bizonyítására, hogy ez a kezelés valóban elősegíti-e a micro- és macrovascularis szövődmények kivédését, illetve a már kialakult szövődmények progressziójának lassítását.

Közlésre érkezett: 2019. január 20.

Közlésre elfogadva: 2019. február 22.

A szerzö levelezési címe:

Prof. Dr. Gerő László

Semmelweis Egyetem, I. sz. Belgyógyászati Klinika

1083 Budapest, Korányi Sándor u. 2/a

E-mail: gero@bel1.sote.hu 


\section{rrodalom}

1. Heise $\mathrm{T}$, Mathieu C: Impact of the mode of protraction of basal insulin therapies on their pharmacokinetic and pharmacodynamic properties and resulting outcomes. Diabetes Obes Metab 2017; 19: 3-12. doi:10.1111/dom.12782

2. Ashwell SG, Gebbie J, Home PD: Twice-daily compared with once-daily insulin glargine in people with type 1 diabetes using meal-time insulin aspart. Diabet Med 2006; 23: 879-886. doi:10.1111/j.1464-5491.2006.01913.x

3. Albright ES, Desmond R, Bell DSH: Efficacy of conversion from bed-time $\mathrm{NPH}$ insulin injection to once- or twice-daily injections of insulin glargine in type 1 diabetic patients using basal/bolus therapy. Diabetes Care 2004; 27: 632-633. doi:10.2337/diacare.27.2.632

4. Hollander P, Cooper J, Bregnhoj J, Pedersen OB: A 52-week, multinational, open-label, parallel-group, noninferiority, treat-to-target trial comparinginsulin detemir with insulin glargine in a basal-bolus regimen with mealtime insulin aspart in patients with type 2 diabetes. Clin Ther 2008; 30: 1976-1987. doi:10.1016/j.clinthera.2008.11.001

5. Rosenstock J, Davies M, Home PD, Larsen J, Koenen C, Scherthaner G: A randomized, F52-week, treat-to-target trial comparing insulin detemir with insulin glargine when administered as add-on to glucose-lowering drugs in insulin-naive people with type 2 diabetes. Diabetologia 2008; 51: 406-416. doi:10.1007/s00125-007-0911-x

6. Jonassen I, Havelund S, Hoeg-Jensen T, Steensgard $D B$, Wahlund PO, Ribel U: Design of the novel protraction mechanism of insulin degludec, an ultra-long-acting basal insulin. Pharm Res 2012; 29: 2104-2114. doi:10.1007/s11095-012-0739-z

7. Gerō L: Degludek-inzulin (Tresiba) (in: Gerō L, Jermendy Gy: Inzulinanalógok a klinikai gyakorlatban. Medicina Kiadó Zrt, Budapest, 2014.) pp. 103-115.

8. Ceriello A, Kilpatrik ES: Glycemic variability: both sides of the story. Diabetes Care 2013; 36(Suppl. 2): S272-S275. doi:10.2337/dcS13-2030

9. Stahn A, Pistrosch F, Ganz X, Teige M, Koehler C, Borstein S, et al:. Relationship between hypoglycemic episodes and ventricular arrhythmias in patients with type 2 diabetes and cardiovascular diseases: silent hypoglycemias and silent arrhythmias. Diabetes Care 2014; 37:516-520. doi:10.2337/dc13-0600

10. Clark AL, Best CJ,2 Fisher SJ: Even silent hypoglycemia induces cardiac arrhythmias. Diabetes 2014; 63: 1457-1459. doi:10.2337/db14-0108

11. Brod M, Wolden M, Christensen T, Bushnell DM: A nine country study of the burden of non-severe nocturnal hypoglycaemic events on diabetes management and daily function. Diab Obes Metab 2013; 15: 546-557. doi:10.1111/dom. 12070

12. Heise T, Hermanski I Nosek L, Feldman A, Rasmussen S, Haahr H: Insulin degludec: four times lower pharmacokodynamic variability than insulin glargine under steady state conditions in type 1 diabetes. Diabet Obes Metab 2012; 14: 859-864. doi:10.1111/j.1463-1326.2012.01627.x

13. Heise T, Hövelmann U, Nosek L, Hermanski L, Bottcher SG, Haahr H.: Comparison of the pharmacokinetic and pharmacodynamic profiles of insulin degludec and insulin glargine. Exp Opin Drug Metab Toxicol 2015; 11: 1193-1201. doi:10.1517/17425255.2015.1058779

14. Heise T, Nørskov M, Nosek L, Kaplan K, Famulla S, Haahr HL: Insulin degludec: lower day-to-day and within-day variability in pharmacodynamic response compared with insulin glargine $300 \mathrm{U} / \mathrm{ml}$ in type 1 diabetes. Diabet Obes Metab 2017; 19: 1032-1039. doi:10.1111/dom.12938

15. Bailey TS, Pettus J, Roussel R, Schmider W, Maroccia M, Nassr N, et al.: Morning administration of $0.4 \mathrm{U} / \mathrm{kg} /$ day insulin glargine $300 \mathrm{U} / \mathrm{mL}$ provides less fluctuating 24-hourpharmacodynamics and more even pharmacokinetic profiles compared with insulin degludec $100 \mathrm{U} / \mathrm{mL}$ in type 1 diabetes. Diabet Metab 2018; 44: 15-21. doi:10.1016/j.diabet.2017.10.001
16. Heise T, Heckermann S, DeVries JH: Variability of insulin degludec and glargine U300: A matter of methodology or just marketing? Diabetes Obes Metab 2018; 20: 2051-2056. doi:10.1111/dom. 13365

17. Korsatko S, Deller S, Koehler G, Mader JK, Neubauer K, Adrian CL, et al: A comparison of the steady-state pharmacokinetic and pharmacodynamic profiles of 100 and $300 \mathrm{U} / \mathrm{mL}$ formulations of ultra-long-acting insulin degludec. Clin Drug Investig 2013; 33: 515-521. doi:10.1007/s40261-013-0096-7

18. International Hypoglycaemia Study Group: Glucose concentration of less than $3,0 \mathrm{mmol} / \mathrm{L}(54 \mathrm{mg} / \mathrm{dL})$ should be reported in clinical trials: a joint position statement of the American Diabetes Association and the European Association for the Study of Diabetes. Diabetes Care 2017; 40: 155-157. doi:10.2337/dc16-2215

19. Riddle MC, Rosenstock J, Gerich J and the Inssulin Glargine 4002 Study Investigators: The treat-to-target trial: randomized addition of glargine or human NPH insulin to oral therapy of type 2 diabetic patients. Diabetes Care 2003; 26: 3080-3086. doi:10.2337/diacare.26.11.3080

20. Wangnoo SK, Chowdhury S, Rao PV: Treating to target in type 2 diabetes: the BEGIN trial programme. J Assoc Physicians India 2014; 62: 21-26.

21. Lane W, Bailey TS, Gerety G, Gumprecht J, Philis-Tsimikas A, Hansen CT, et al.: Effect of insulin degludec vs. insulin glargin U100 on hypoglycemia in patients with type 2 diabetes. The SWITCH 1 randomized clinical trial. JAMA 2017; 318: 33-44. doi:10.1001/jama.2017.7115

22. Wysham C, Bhargava A, Chaykin L, de la Rosa R, Handelsman Y, Troelsen LN, et al: Effect of insulin degludec vs. insulin glargin U100 on hypoglycemia in patients with type 1 diabetes. The SWITCH 2 randomized clinical trial. JAMA 2017; 318: 45-56. doi:10.1001/jama.2017.7117

23. Marso SP, McGuirre DK, Zinman B, Poulter NP, Emerson S, Pieber TR, et al.: Efficacy and safety of degludec vs. glargine in type 2 diabetes. N Engl J Med 2017; 377: 723-732. doi:10.1056/NEJMoa1615692

24. Rosenstock J, Cheng A, Ritzel R, Bosnyak J, Devisme C, Cali AMG, et al.: More similarities than differences testing insulin glargin 300 units $/ \mathrm{mL}$ vs. insulin degludec 100 units $/ \mathrm{mL}$ in insulin-naive type 2 diabetes: the randomized head-to-head BRIGHT trial. Diabetes Care 2018; 41: 2147-2154. doi: $10.2337 / d c 18-0559$

25. The Diabetes Control and Complications Trial (DCCT) Epidemiology of Diabetes Interventions and Complications (EDIC) Study Research Group: Intensive diabetes treatment and cardiovascular outcomes in type 1 diabetes: the DCCT/EDIC Study 30-year follow-up. Diabetes Care 2016; 39: 686-693. doi:10.2337/dc15-1990

26. Tibaldi J, Haldrup S, Sandberg V, Wolden MW, Rodbard HW: Clinical Outcome Assessment of the Effectiveness of Insulin Degludec (Degludec) in Reallife Medical Practice (CONFIRM) - A Comparative Effectiveness Study of Degludec and Insulin Glargine 300U/mL (Glargine U300) in Insulin-Naïve Patients with Type 2 Diabetes (T2D). Diabetes 2018; 67(Suppl. 1.): 98-LB. doi:10.2337/db18-98-LB

27. The Diabetes Control and Complications Trial Research Group: The effect of intensive treatment of diabetes on the development and progression of long-term complications of insulin-dependent diabetes mellitus. N Engl J Med 1993; 329: 986-997. doi:10.1056/NEJM199309303291401

28. Nathan DM, Cleary PA, Backlund JY, Genuth SM, Lachin JM, Orchard T/J, et al.: Intensive diabetes treatment and cardiovascular disease in patients with type 1 diabetes. N Engl J Med 2005; 353: 2643-2653. doi:10.1056/NEJMoa052187

29. UK Prospective Diabetes Study (UKPDS) Group: Intensive blood glucose control with sulphonylureas or insulin compared with conventional treatment and risk of complications in patients with type 2 diabetes (UKPDS 33). Lancet 1998; 352: 837-853. doi:10.1016/50140-6736(98)07019-6

30. Holman RR, Paul SK, Bethel MA, Matthews DR, Neil AW: 10-year followup of intensive glucose control in type 2 diabetes. N Engl J Med 2008; 359: 1577-1589. doi:10.1056/NEJMoa0806470 